\title{
結晶の多形と相転移
}

Polymorphism and Phase Transition Phenomena in Crystals

関 集 $\Xi^{*}($ Syâzô Seki)

I . 序

物質の相転移 (phase transition, phase transformation)( 又は相変化)は, 古くからしられている現象であるが，この現象は，統計力学の立場からは，今日でも未だ 原子論的な統一的解採のむずかしい，しかも興味ある問題である。

さて，熱力学的な立場から，可逆的な相変化をくわしく研究したのはJ.Black の水の 融解現象が最初のものといわれている(1755)。この研究はその後, 有名なクラウジウス. クラベイロンの式に発展し, 第二法則の実験的裏付とな $n$, 熱力学的相転移の研究の基礎 を与えた。

一方, 結晶の多形 ( polymorph) についてはK Iaproth ( 1788 )の方解石とあられ 石の研究以来, 次第に多くの鉱物・結晶学者, 冶金学者, 物理・化学者の関心を惹き, 19 世紀に入ってからは，外形的な観察と生成方法，その熱力学的考察がすすめられ，きわめ て多数の物質について多形の存在が明らかにされた。

多形現象（元素から出来ている結晶の場合には，allotrope*の中にそれをふくめて いる)の内容の説明として, 既て 1809 年, H. Davyは, ダイヤモンドと石墨の羙異を結 晶内原子の配列の差として説明しているが，20世紀になってX線的方法が用いられてか ら, 相変化の原子論的説明が一層くわしく行なわれるようになって, この問題は再び新し い立場からみられるようになった。

今日では, ほとんどあらゆる物質構造決定方法, 物性測定方法が相転移の研究に利用さ れており，同時に，特定の性質、性能をもった材料をつくるマテリアル・サイエンスの立 場からも相変化の研究はゆるがせに出来ないものとなっている。結晶の多形とその相变化

- 大阪大学理学部化学教室

" 参考文献: W. E. Addison, The allotropy of the Hlements, Oldbourne Press London (1964) 
の研究は, 多くの他の相变化即ち, 結晶の直接関係しない相変化に比べて, 特に原子, 分 子の配列の相互の関釈が明らかにできる点で埋論的にも実験的にももっともくわしい研究 がなされて来たわけである。

\section{II. 相変化の種類}

さて，結晶相間の相変化について話をすすめるに先立って結晶状態というものが純物質 の種々の相変化に拈いてどのような位置をしめているかを主として温度変化に重点を拈い て図1に示して扣こう。

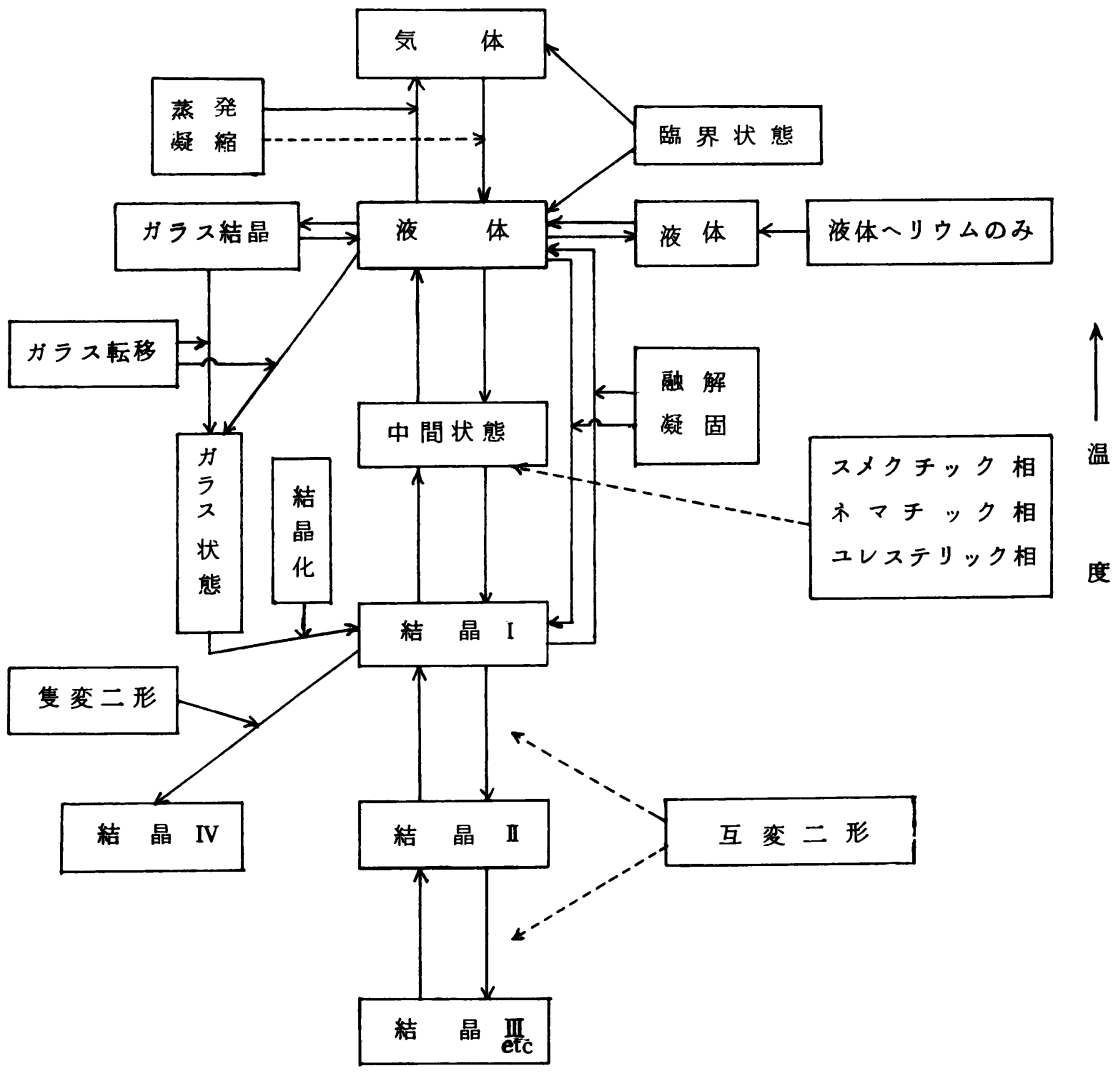


この図について蛇足ではあるが二，三の点を注意して抗こっむず気体と液体との間には 臨界点があるが, 液体と固体の間には臨界点がない。中間状態にはスメクチック・ネマチ ック或いはユレステリック等の相があり, これらは互変二形のものも隻変二形のものもあ り，むた中閒相をしめす物質が必ずしもこれらのすべての相を示す場合もあれば，そうで ないものもある。液体が過冷状態からさらに冷却されるとガラス転移点 (T8 ) を経てガラ 状態にらつるものが多くしられているが，これは果して相変化であるか緩和現象である か, むしろ後者であろ5とい5見方が強い。液体が㠜固して結晶になりながら, しかもが ラス転移を示す物質も最近注目されており, 或いみでガラス性結晶（glassy crystals） とも乎ぶことが出来る相が柔粘性結晶（plastic crystals）においてしられている。

次に結晶相間の相転移にらつるが，今回は結晶の間の互変二形（ enantiotropie）な 相変化の熱的変化を中心に話しを限ることを㧊るしいただくことし，その前に，分子 又は原子の運動状態と相変化の相互の関係に若干ふれておこう。

第 2 図(a) 結晶状態

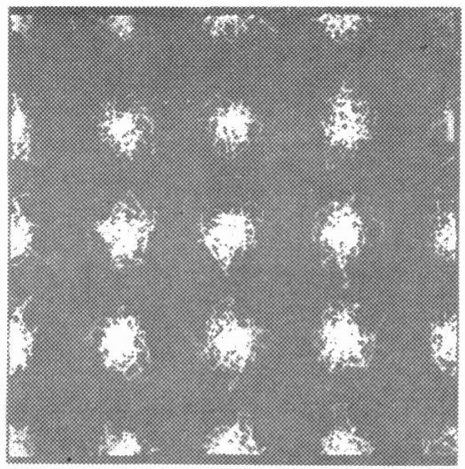

第 2 図(b) 融点直上の液体状態

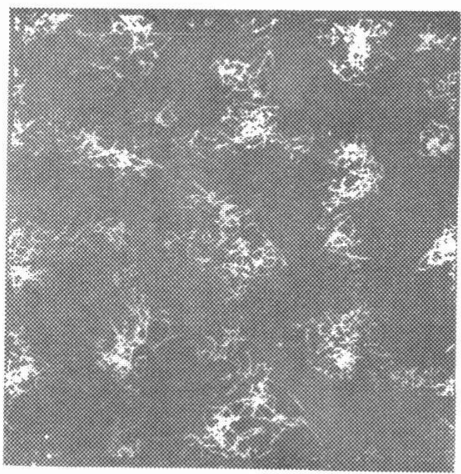

第 2 図(c) 気泡の出初めた液休

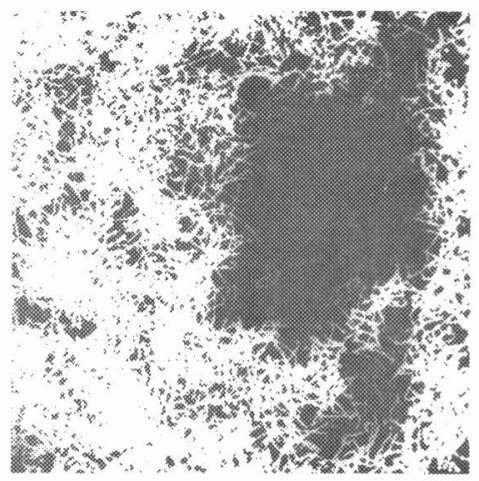

第 2 図(d) 気相 液相共存状態

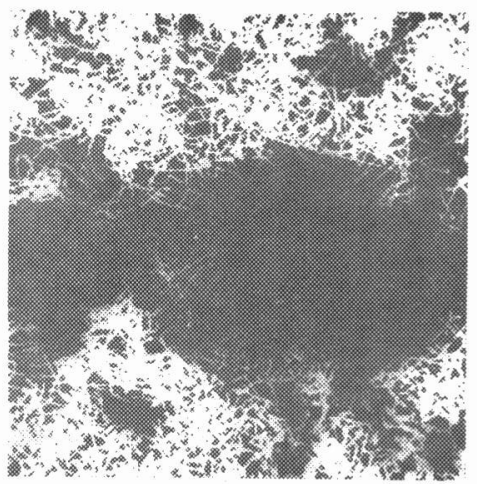


第 2 図に最近, カリフォルニヤ大学の Aldenと Wainwright等が行なった分子運動の 電子計算機によるモデル研究の結果を示してある。彼等はアルゴンの分子間功いての 知識 - 通常分子間力としていわゆる Lennara- Iones potentialの名でしられてい る- $\mathrm{Ar}{ }^{-6}+\mathrm{Br}^{-12}$ のポテンシャルを用いて，数百個の分子集団についてその分子運動と分 子配列をしらべた。その結果については，絶えず熱的平衡状態としてのボルツマン分布を 考慮してたしかめて計算機へかけてその分子運動の軌跡をブラウン管上に撮影したのがこ の第 2 図である。もちろん二次元的相状態であるが，(a)は，結晶状態に対応して分子の重 心は規則正しく配列され，分子運動としては重心を中心に振動が観測される。（b)は䖨解 直後に対応し，未だ結晶に近い格子構造がのこっていて，いわゆる短距離秩序性 (shortrange order）がのこっているが，既に一部の分子は他の分子のしめていた位置と旺んに 位置の交換を行なって扰り，振動運動が発展して移行運動がみられる一即ち自己抁散 （self-diffusion）がおこっている。温度が上䄯するとこの short range order は, 挔散的移行運動で益々減少し，格子的性格がみられなくなり(c)図に見るように液体の一部 に逆に空隚がみら九, 気泡の発生, 即ち蒸発現象が扣こっている。秋空の飛行機雲のよう な分子の長距離の直線飛行運動が観測される。

以上は極めて簡単な単原子分子 ( 球形対称 ) の数百個程度の集団の二次元モデルにすぎ ないが，しかし，分子運動と相変化の関係を眼でみたよろに示している点で甚だ教育的で あろ5。実際の $10^{23}$ 個もの, しかも球対象からずれた多原子分子の集団としてのマク口 スコピックな物質では勿論, これよりもはるかに複雑な挙動をしめすからこそ, 第 1 図に 示したようなさまざまの結晶の多形転移や他の多くの中間状態等か佚現されるわけである。 III.物質の集合状態 - 相の熱力学的考察

よくしられているように物質の安定状態は一定圧力下では Gibbs エネルギー最低の状 態として熱力学的に導かれる。ある相が，他の相に比へでり安定であるかどうかを知る ためにはGibbs エネルギーを測定してより低いことを知ればよい。通常圧力と温度のみ の関数としてGー值をしらべると第 3 図呩したような Gibbs エネルギー曲面が得られ， 曲面の交線として蒸発，融解，犁華曲線，またこれらの曲線の終点としての踟界点，交点 としての三重点がえられる。これらのG 值を一定にして二次元 $(P, T$ 座標 )に投影したも 加通常, 状態図 (phase diagram) とよばれる。

さて，Gの值を実測するにはどうするかというと，これも熱力学の初歩的問題で恐縮で あるが，一応第 4 四によって説明しておこう。

図で明らかなようにエンタルピー，Hは温度と共に上昇し，たとえばある $T_{\mathfrak{t}}$ の温度で 一次の相変化（クラウジウスークラペイロンの式が成立する）をおこすと潜熱 $\Delta \mathrm{H}_{\mathrm{t}}$ を伴っ て高温相にうつる。この より,エンタルピーヌは転移熱を決定できる。 


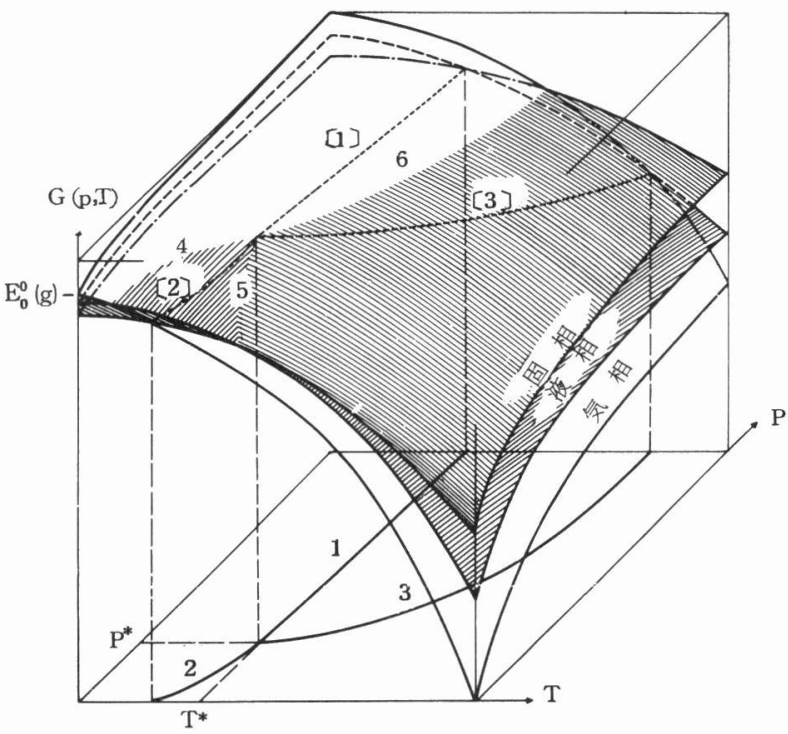

第 3 図(b) 気 - 液臨界点付近の Gibbs エネルギー曲面想像図

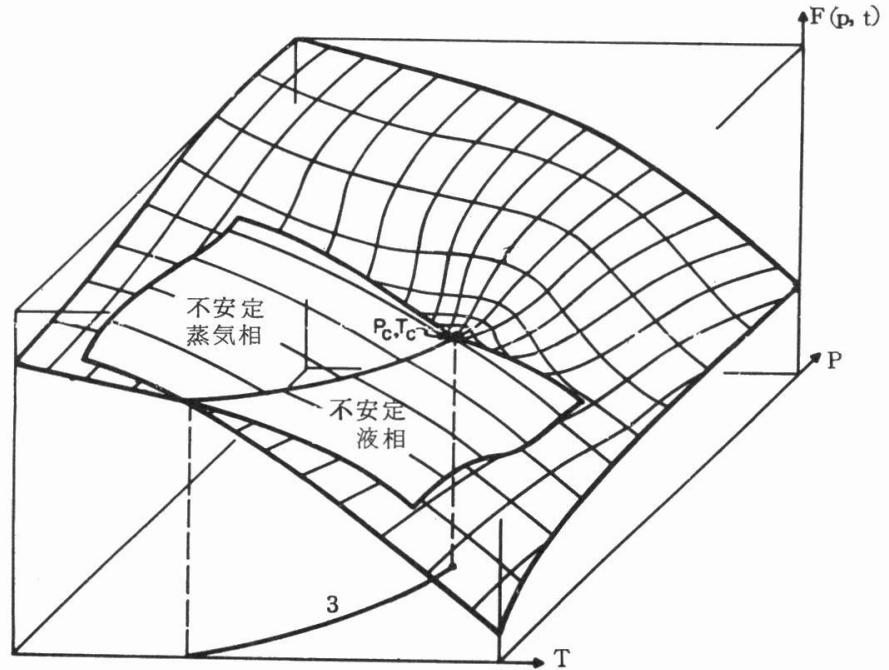


第 4 図

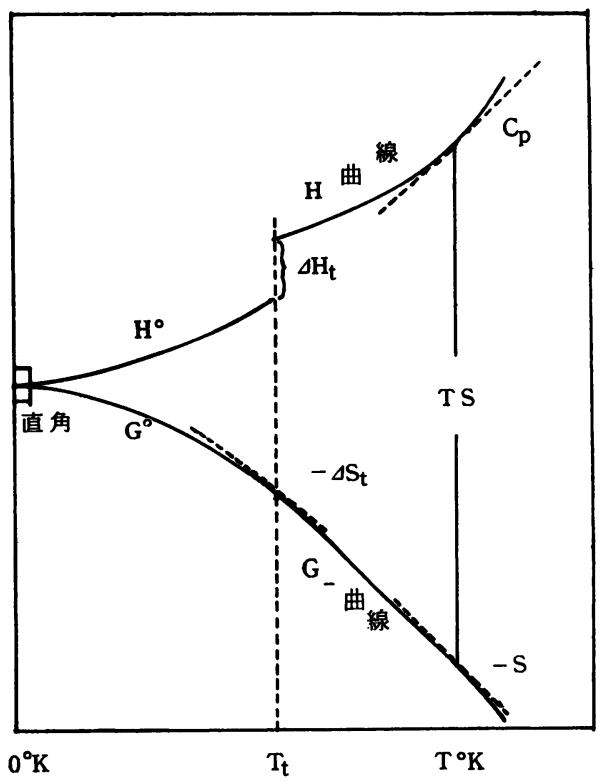

一方、Gibbsエネルギーは温度上界と共に降下することは，その温度勾配がーSである ことから容易にわかる。転移点 $T_{\mathfrak{t}}$ で $G$ 曲線は交叉して別の曲線にうつるが，これも一次 の相転移の場合である。 $\mathrm{G}=\mathrm{H}-\mathrm{T}$ S の繁力学的関保から明らかなようにある温度でのH曲線とG曲線の值の差は T S である。ところで $\mathrm{S}=\int\left(\mathrm{C}_{\mathrm{p}} / \mathrm{T}\right) \mathrm{d}$ T の関保から明らかなよ 万に $\mathrm{S}$ は $\mathrm{C}_{\mathrm{p}}$ の測定から求められる。このようにして $\mathrm{H}$ も $\mathrm{S}$ も $\mathrm{C}_{\mathrm{p}}$ から求められるので 結局，ギブスエネルギーは $\mathrm{C}_{\mathrm{p}}$ を精確に測定することに帰せられる。

比熱を極低温から目的の温度までの温度領域に亘って測定するのは現在でも可成り面倒 な仕事である。くわしいことは一切省略するが，低温領域では今日，断熱型のカロリメー ターが多く利用されて扣り，高温領域でも次第にこの型が普及しつつある。しかし，高温 ではいろんな制約のため, いわゆる投下式恒温カロリメーターもよく利用されている。特 に比熱測定で大切なことは，温度を国際実用目盛に準拠して正確に定めること，熟エネル ギーの供給源としての電気量の精密測定，物質の純度の今味等であろ万。第 5 図には我々 の研究室て用いているカロリメーターの一部と測定装置の一部を示してある。また第 6 図 は，この種比熱計の精度桧定のための国際標準物質の安息香酸の比熱から見た装置の精度 
第 5 図(a) 低温 $\left(12^{\circ} \sim 300^{\circ} \mathrm{K}\right)$ 用自働制御式断熱カロリメーター

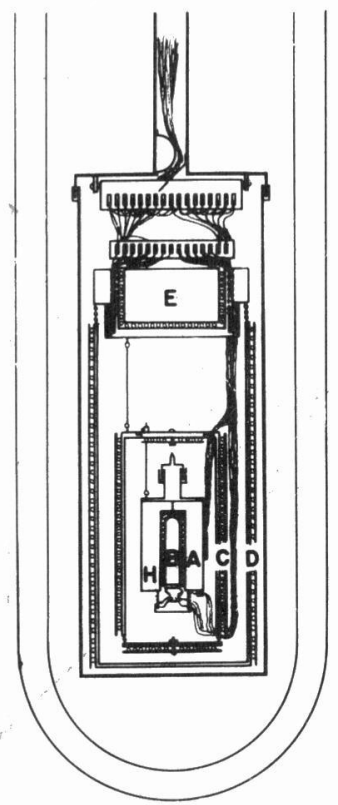

第 5 図(b) 筆者研究室の比熱測定台（左側：温度記録，右側：温度制御装置）

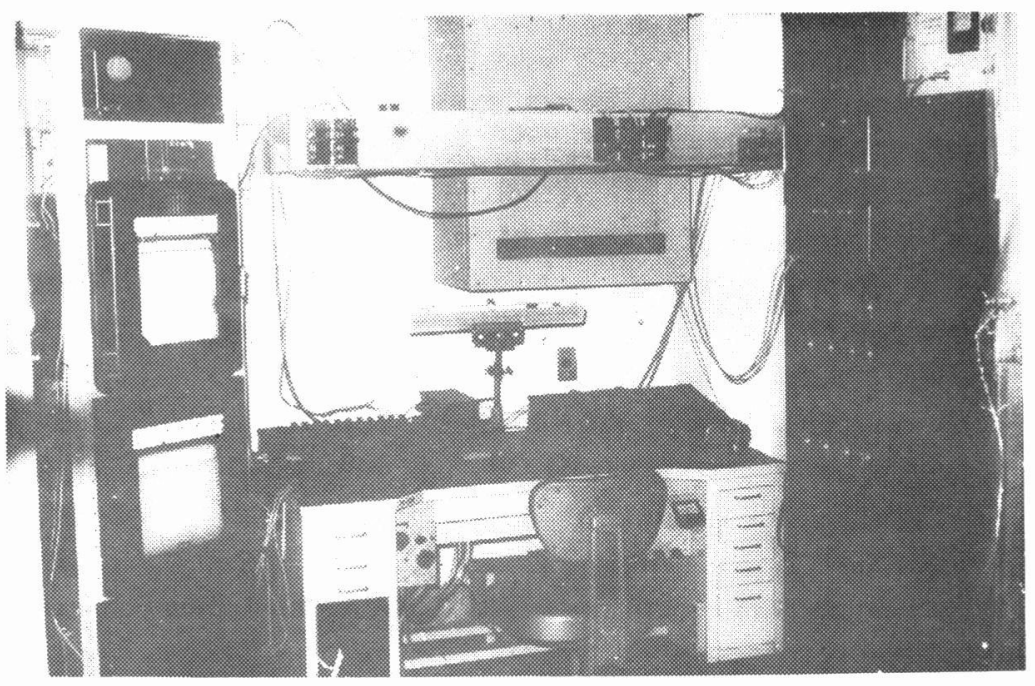


第 6 図 比熱標準物質の安臭香酸（国際䅺凖）を用いて倹定した測定装置の 精度曲線（縦軸が平均偏差走示す）

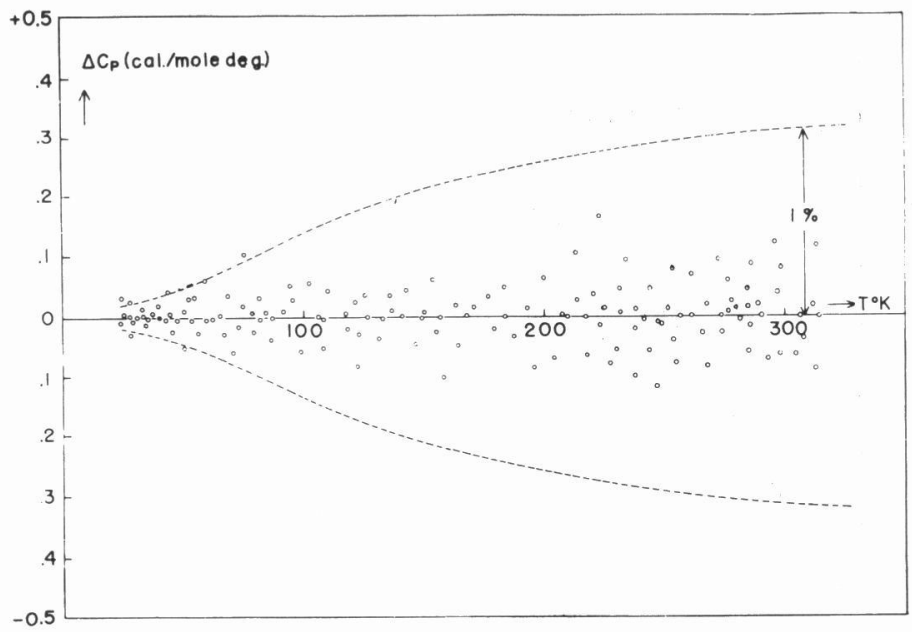

表ともいうべき曲線である。この比熱計を用いて測定した一例として $\mathrm{K}_{2} \mathrm{CuCl} \cdot 2 \mathrm{H}_{2} \mathrm{O} の$ 比熱曲線と $\left(\mathrm{NH}_{\mathbf{4}}\right)_{\mathbf{2}} \mathrm{CuC} \mathbf{A}_{\mathbf{4}} \cdot 2 \mathrm{H}_{\mathbf{2}} \mathrm{O}$ のそれを同一の第7㲸に示した。この二つの結晶は同 形であるが、アンモニウム塩の方では後述のよらにアンモニウム基の回転的振動の自由度 の変化に伴ら高次の相転移（約 $200^{\circ} \mathrm{K}$ 付近）(一次の相転移のよらに比熱が無限大になら ないものの総称 )を伴うことが見られるであうう。

尚, カロリメーターの話を終るにあたって, 鉱物等にみられる非常にゆるやかな徐々に 発熱又は吸熱支伴う相転移の研究に利用できるCalvet型力口リメーターの一例走第8図 に示して抗う。この図のものでは0.001 ca】 hr 程度のきわめて長時間に亘っての微量 の熱の出入を測定できるが, 形式としては双子型䓡伝導式恒瑥壁カロリメーターとよぶこ とができる。 
第 7 図(a) $\mathrm{K}_{2} \mathrm{CuCl}_{4} \cdot 2 \mathrm{H}_{2}$ Oの熱容量の温度変化曲線

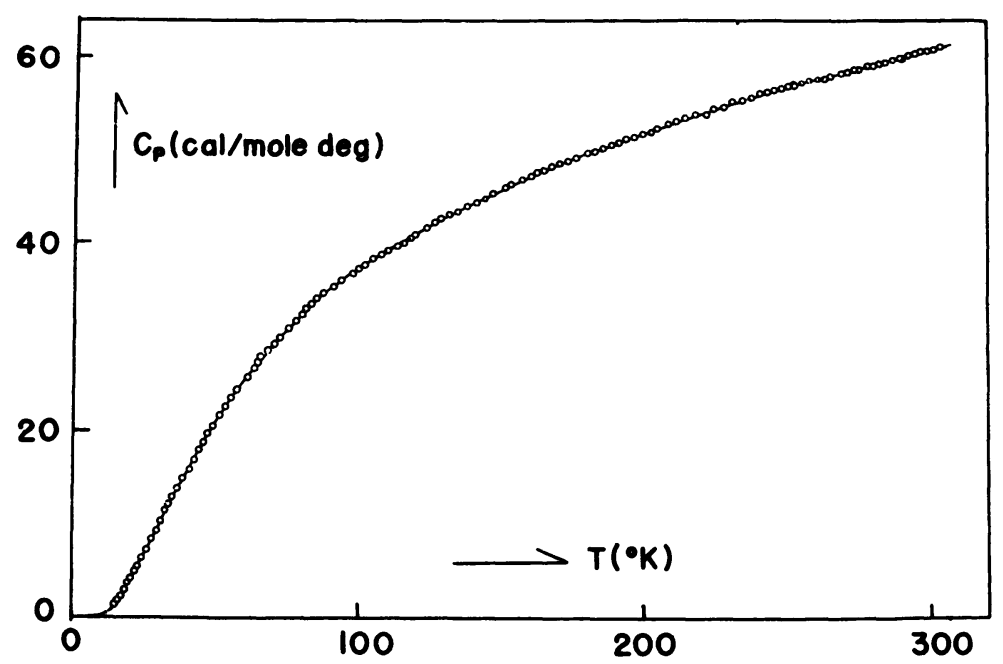

第7四(D) $\left(\mathrm{N} \mathrm{H}_{6}\right)_{2} \mathrm{Cu} \mathrm{Cl} \cdot 2 \mathrm{H}_{2} \mathrm{O}$ の比熱曲線

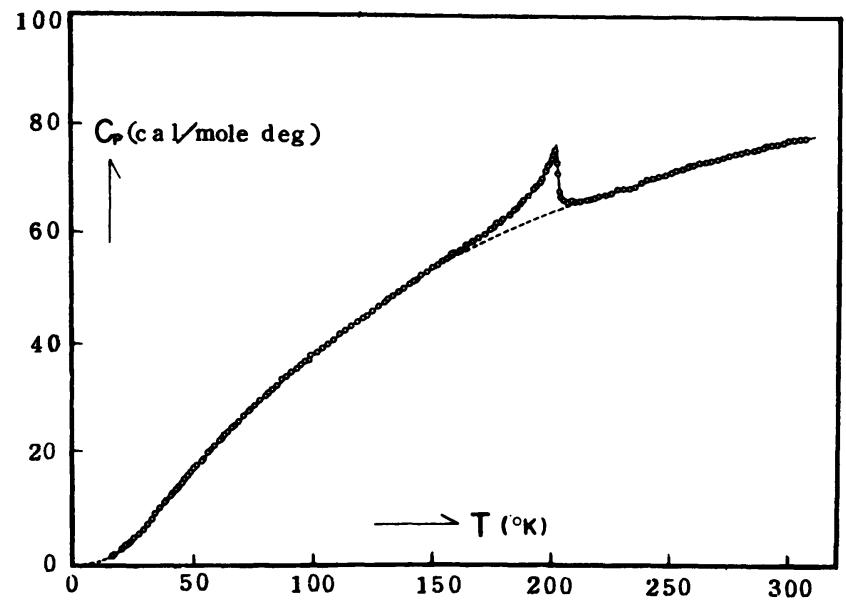




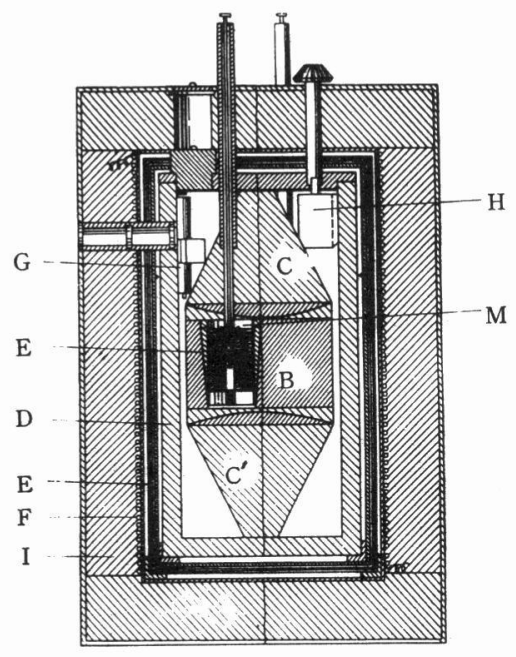

IV. 私共の研究室での研究とそれに関連した研究例

我々の研究室でこれまで無機, 有機の多数の結晶について比熱の測定を行なって来たが, こ〉ではその中から，時間の関係もあるので歴史的順序には必ずしも従わないで，簡単な 例からやや複雑な例に亘っての゙ることとしよう。もっとも, 複雑といっても, 鉱物学者 の皆様の取扱われる物質からみればはるかに簡単なものしか研究していないことを予め拉 断りしてお゙ゆるしをいただきたいと思う。

先ず単原子分子としてのアルゴンとキセノンの低温比熱に簡単にふれて拝こら。これら の結晶の内での分子間の振動は光学的方法では観測されないからどらしても薙的方法か有 力となる。比熱則定の結果から振動数の分布をしらべる方法が最近次第に発展してきてい るが,このような簡単な分子でも，その振動数の分布 一 即ちどのような振動がどの位の 割合で存在するかーをしらべると Debyeが提出した振動数分布式 (即ち, 振動数レと $\nu+d \nu$ の間に存在する振動子の数を $f(\nu)$ d $\nu$ とする $f(\nu) \propto \alpha \nu^{2}$ で与えられる)から 可成りづれている。ここでは相転移に関連した問題として,アルゴン結晶の前融解現象 （premelting）についでけふれて抗こう。即ち,この結晶の極めて純度の高いもので もその比熱曲線が融点より可成り低温よりその值が正常值より立上りをしめすのである。 この現象は，金属にも見られる場合が知られており，これを格子欠陥 (lattice defect) 
の生成として説明するとその格子久楩の数 $\mathrm{n}_{\mathbf{8}}$ と格子点の数 $\mathrm{N}$ との間に $\mathrm{N}_{\mathrm{B}} / \mathrm{N}=30$ exp ( $-1280 / \mathrm{RT})$ の関係がみちびかれ，融点直下で欠陥は $1.5 \%$ ，欠陥をつくるに必要な エネルギーは1280 cal/mol となる。拉そらくこのような欠陥の生成と共に自己拻散も 生じているであろうことは他の多くの例からも想像できる。

二原子分子の例にらつる。からて我々の研究室でやられた千原教授等のハロゲン分子性 結晶についての興味ある結果については講演会では紹介したが、ここではむしろその時に 余りくわしくふれなかった同様の考え方の一例として，むしろ鉱物学者の関心の深いイオ ン結晶のアルカリシアン化物の場合を説明する。

先ず K CNの例を説明しよう。この結晶の比熱を低温から測定すると第 9 図のようにな n, 二つの比熱異常を伴う高次の相転移が見出された。室温では等軸晶系の結晶であり，

\section{第 9 図 KC N 結晶の比熱曲線}

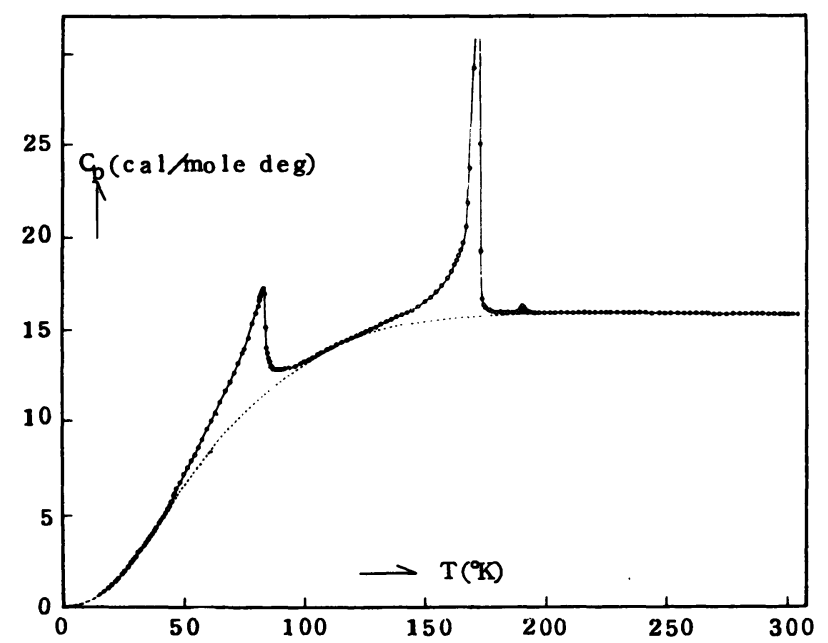

$\mathrm{CN}^{-}$イオンの見掛上の対称性が上っている。このことと転移のエントロピー変化 $\Delta \mathrm{S}_{\mathrm{t}}$ と を結びつけて，少しくわしくのへよう。先づ高温側ピーク面積からの $\Delta$ 、を比熱から求 めると, この值は Boltzmannの関保式 $\mathrm{s}=\mathrm{k}$ In $\mathrm{W}$ を用いると $\mathrm{W} \cong 4$ の值になる。即 ち， $\mathrm{C} \mathrm{N}^{-}$基は等軸晶系の単位格子の体中心にあって 4 つの体対角線に統計的に同等に分 布していることがわかった。この時の $\mathrm{CN}^{-}$基の連動は決して自由迴転ではないことはこ 
のことからもわかるが，その一つの向きから他の配向にうつる時に越えねばならないポテ ンシャルの山高さも比熱值の解析から求められ, 約 $1350 \mathrm{cal} / \mathrm{mol}$ となる。これを低 温に下げると分子の四つの配向の自由度が失われ，斜方晶系の結晶に転移するが，更に転 移を起して最低温相にうつる。この時の $\Delta \mathrm{S}_{\mathrm{t}}$ の值をしらべると $\mathrm{w} \simeq 2$ となり，このことは $\mathrm{CN}^{-}$基の頭と尻尾の見別けのつかなかった状態力ら C と Nの見別けのつく状態に移ること をいみしていると考えられ，高温相で C N と N C の区別のない disorderの状態から C N が一方向に整列した orderの状態に移ることになる。尚, 最低温相の比愁を解析すると, $\mathrm{C}-\mathrm{N}$ 基の格子内での"くびふり運動 "の振動数も計算され，約 $160 \mathrm{~cm}^{-1}$ の值が得られ た。

アルカリ金属としての K と代りにNaにした NaCN の場合にもこれと同様の比熱曲線力得 られる(第 10 図参照 )か;，Cs 塩，Rb塩になるとむはや転移点は一つになってしま5。 この場合は $\Delta \mathrm{S}_{\mathrm{t}}=\mathrm{R}$ In 4 の転移のみしか観測されないので，おそらく CN と NC の区別は disorderのままで極低温まで倲結されてしまうすのと考えられる。尚アルカリ金属の代 りに TI+を入れかえたものでは，三つの相転移点が見出され，この場合 $\mathrm{T} 1$ 原子核の核磁 気共鳴の研究の結果, イオン間相互作用に共有結合性が示されるので転移の様子も大きく 変化することが推定された。

第 10 図 $\mathrm{NaCN}$ 結晶の比熱曲線

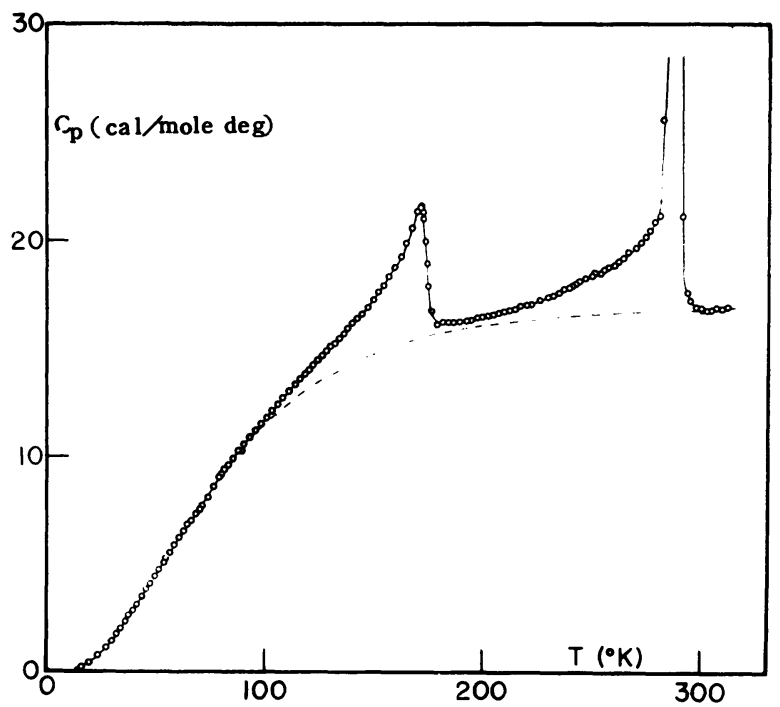


二原子分子の例から三原子分子の例にらつる。 CN の代りに S CNでおきかえたKSCN

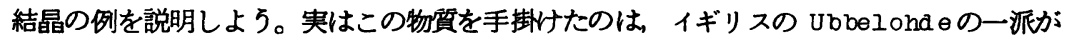
この結晶の熱胿長の異常と前敐解現象を発表していたからである。第 11 図に示すよ5に 彼等のデーターでは $150^{\circ} \mathrm{C}$ 付近で測定点が可成りみだれており，この付近から m.p. ま で異常な熱剅長がある。彼等はこれを説明するのに格子欠陥の生成とイオンの自己拡散と していたが，我々は充分精製したるのについて測定した結果， $150{ }^{\circ} \mathrm{C}$ 付近に新しい転移 を見出した。しかもこの転移は $\Delta \mathrm{S}$ かから R n 2 に等しいことを見出し $\mathrm{CN}$ 一と NC-の場 合のように $\mathrm{SCN}^{-}$と NCS-の order-disorder転移であることを推定し,さらに X 線的 にもこのことが裏書きされた。一方, 前融解現象は全く見出されず，Ubbelohde等の試 料か不純物の影響を示していることがわかったのである。試料を純粋てすることがいかに

第 11 目 KS C N 結晶の体積温度変化

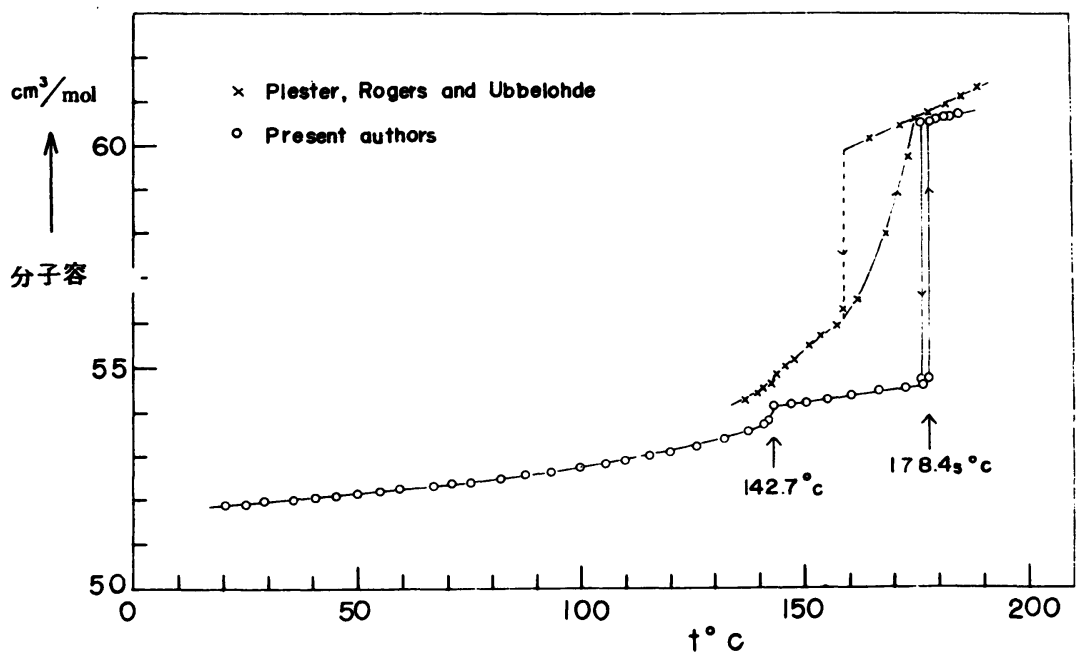

重要かかかかる。

次にアンモニウム塩の相転移とついて研究した一例にふれておこう。よくしられている よ5K N Ha ${ }^{+}$基の格子内の欺向の order-disorder転移は歴史的にももっとも古くから 矿究され，比熱測定以外にもほとんどあらゆる物性研究，構造研究方法力利用されて今日 に到っている。我々もこの塩類の種々のものについて研究を行なって来たが，紙面の都合 ああり，講演会で最後に取上げた NH6 Nosの場合だけをここに紹介しておこう。 
この場合は四面体の $\mathrm{NH}^{+}$イオンの配向の乱れと NOت-正三角形イオンの配向の乱れが相 互に関連しておこるために多くの転移点がしられている゙。その結果, 示差熱分析 ( D T A ) を行なら研究者は，その使用する装置の性能をしらべるために一度は必ずこの物質の相転 移をしらべる程によくしられた相変化である。にもかかからず, 未だにすべての相転移に ついて一貫した精密な測定か行なわれていなかった。しかし低温の比熱については M I T のS tephenson 等の精密な信頼し5 る測定があったので測定の必要性はそれほどなかった。 ところか昨年（1965)になってドイツの Eichenauer 等は Stephensonの上記のデー ターは誤っているとのへてて新しい結果を発表した。たまたま, 我々の研究室ではこの結晶 のIV相，III相，II相の出現条件と過冷，過熱の関保をしらべる興味もあって上記の二人の データーの何れか正しいかを早急に決定する必要に迫られた。またIII，IV相がしばしば実 現されないのはこの相か不安定相であるかど5かということもきめることにも興味があっ た。央測の結果は, 我々のデーターは低温では stephensonのデーターとほとんど 完全 に一致したので Eichenauerのデーターは誤っていることがたしかめられた（第 12 図）。 我々は更に高温用カロリメーターを用いて高温側の転移のエネルギーとエントロピーをむ 決定した。その他 IV， III相の核生成が微量の水分によって大きく支配されることを意識 的にしらべろため。きわめて微量の表面活性阂（オクタデシルアセテート）を表面に付着さ せて測定したところ，第 12 図に示すようにIV，正相を通過してV相とII 相が大きいピー クのある比熱曲線で直接さすばれることをも見出した。このことは Amorosの低温結晶構 造の解析と山口大の新中博士の研究さ㣗た高温相（II 相）の構造との類似点からもらなう かれる結果である。尚, 序ながら，我々は I相については，直流電気伝導度と高分解能 NMRの研究から，この相では $\mathrm{NH}_{\text {— }}^{+}$イオンの自己払散の起っていることをもたしかめた。 この物質の話しを終るにあたり一言付け加えておきたい。よく，多形の安定，準安定の議 論において，単にその生成の難易からのみ自由エネルギーを推定して，適当な自由エネル ギー曲線の想像図を書いて定性的な議論をすることが多い。しかしこれはあくまでもスぺ キュレーションであることに注意しなければならない。本結晶のIV相やIII相の出現の難易 から，この相助不安定相であると考える人もあった。この様な議論は，その相の比熱値か らGibbsエネルギーを直接決定すれば明らかにされるわけで，われわれは第 13 図のよ5 にGibbs エネルギーを求めたところ，明らかにIV相も III相も安定な相であることがたし かめられたのである。この曲線からむ曲線の交叉している相変化はV $\rightarrow$ II の直接変化を別 としてすべて一次の相転移であることがわかる。

講演会ではアンモニウム塩と関連してアニリン臭化水素化物の相転移の典型的な高次相 転移の比熱曲線，柔粘性結晶としての種々の有機化合物の結晶内分子回転による相転移の 話しをしたが，多くの鉱物学者はこれら有機化合物の相転移について余り御興味がないと

* 高温側から 数えて, I, II, III, IV, V 相が常圧で知られ, 他に高圧安定相 V むしられ ている。 
結晶の多形と相転移

第12図 $\mathrm{NH}_{\mathbf{4}} \mathrm{NO}_{\mathbf{3}}$ の比熱曲線

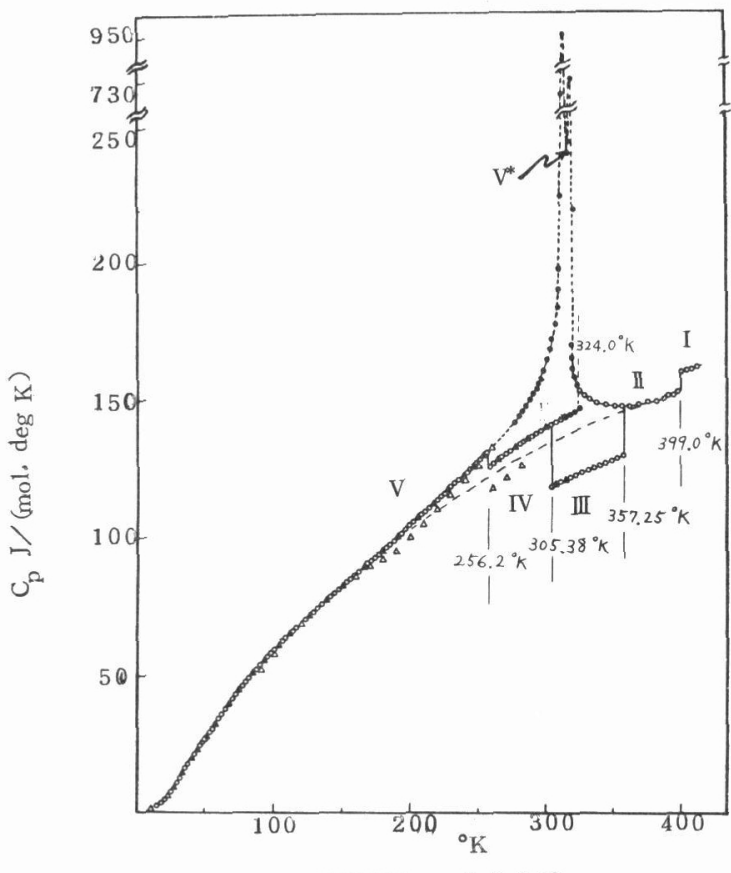

$\mathrm{NH}_{4} \mathrm{NO}_{3}$ の比熱曲線

○純 $\mathrm{NH}_{4} \mathrm{NO}_{3}$, 表面活性剂をふくを $\mathrm{NH}_{4} \mathrm{NO}_{3}$

$\Delta$ Stephenson 等, $\triangle E$ Eichenauer 等

第13図 $\mathrm{NH}_{\mathbf{4}} \mathrm{NO}_{3}$ 結晶の各相の Gibbs エネルギー曲線

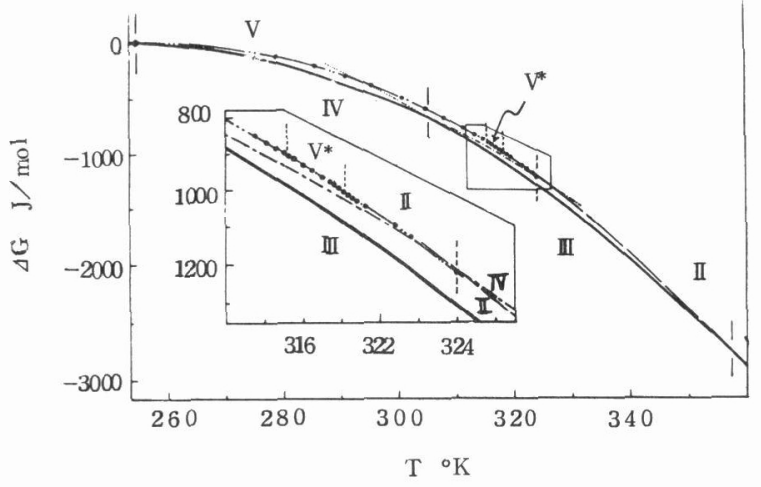

— - - - 準安定相 
思うのでここに再録することはひかえることにしよう。

最後にこれも有機化合物の例で恐縮であるが，ガラス性結晶（glassy crysta工）とも 呼ぶべき相状態を示す物質について我々が最近興味をもって研究したシクロへキサノール ( $\left.\mathrm{C}_{6} \mathrm{H}_{11} \mathrm{OH}\right)$ 話しをしておこ5。

この物質については可成り古くから K. K. Kelleyによる比熱測定が行なわれており， 彼は融点直下の結晶相（これを I-相とよぶ）は過冷されやすくガラス転移に形のよく仩た 比熱異常をしめすことをのべている。このI相は今日の立場からみれば゙柔粘性結晶

（plastic crystal）であるが，この相は徐々に冷却すると別の結晶相(これを【相)に 安定化することを見出した。彼は更にI相のエントロピーとII相のエントロピーの比較か ら過冷却された I相はいわゆる残余エントロピー（residuaI entropy）をもたない熱力 学的な内部平衡にある相で, ガラス状の転移は熱力学的な平衡相間の高次相転移とのべて いる。その後，当時東北大金研の大坪一菅原博士は，上述のガラス転移は安定な相間の相 転移ではなくて緩和現象であろらとした。しかし彼等は残余エントロピーの問題にふれる ほどの精密な実験を行なっていない。しかし，他方，I相からII相にうつる中間でいくつ かの準安定相が存在することをX線にたしかめ，その準安定相の中でも，もっとも安定な 相をIIIー相と命名している。

我々は，従来の測定のくいちがいを明瞭にするため，先づ充分物質を精製した処，果し て、融点はこれまでのものより $3^{\circ} \mathrm{K}$ 高い $99.975 \%$ ののを作製することが出来，こ れを用いて測定をやったのが第 14 図である。我々は更にこの物質の理想気体状態のエン

第 14 図 シクロヘキサノールの比熱曲線

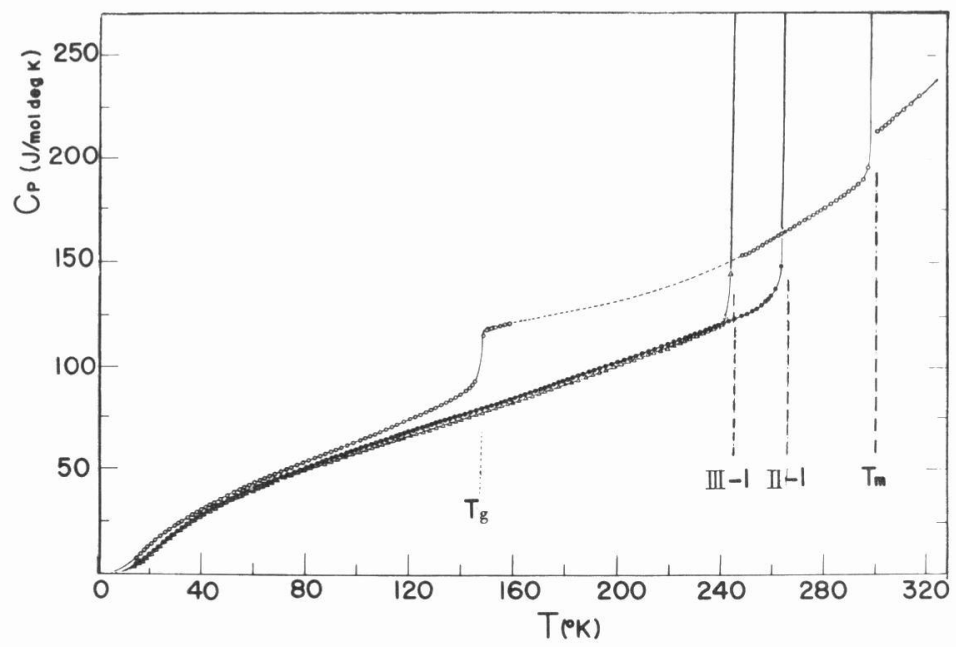

O：I相 ：II 相 $\triangle:$ III 相 
トロピーを分子論的に計算し, 上述の比熱值に蒸気圧, 昇華エンタルピーを組合して求め たエントロピーと比較した結果，I－相は明らかに $4.72 \pm 0.51 \mathrm{~J} /(\mathrm{mol} \operatorname{deg} \mathrm{K})$ の残 余エントロピーをむつことをたしかめ，Kelleyの考が誤りであることをたしかめ，また ガラス転移点が緩和現象であることを再確認した。尚，準安定相のIII相を $100 \%$ 純粋に とり出すことに成功，これについても比熱を測定して（戝参照 ），この相も準安定相であ るにもかかわらず残余エントロピーをむたない熱力学的内部平衡にあることをたしかめた。

このよ5にして, 我々は結晶であるにあかかわらず, 楥和現象としてのガラス転移をし めす相か一つの物質集合状態として実現され，その状態を仮にガラス性結晶と名付けるな らばそその椂な状態では残余エントロピーか存在し，熱力学的な内部平衡にないことをた しかめたのである。

分子の重心は三次元的に結晶格子を形成しても，分子の配向その他の運動の自由度がガ ラス状に東結してでたらめになっている物質については今後、次第に多くの例゙見出され ることか期待され，我々の研究室でもそのような物質を探究している。

以上, 極めて限られた紙面で, 昨年の講演会で報告しました内容の一部について紹介し た次第です。何等かお役に立つことが出来ましたなら望外の喜びと存じます。

\section{〔討綸〕}

定 永：結晶における vibrational entropyの point defectによる増減について 御教示いただきたい。

藤 田：定永先生の御質問に関してコメントを申し上ゲます。格子欠陌が生じた場合に振 動数が低い側に移って振動のエントロピーが増加すると考えるのは原子空孔の場合には恐 らく正しく，その状況は単純な質量とバネでつくった格子モデルの中で一つの質量球を抜 いた場合で考えるとうなゔけますが，同じモデルで格子間原子を入れてみると，まわりの 原子の振動数は逆に上り，エントロピーは減ることになりますので，結局格子欠陥の種類 によって振動エントロピーの変化は増减どちらになるかは必ずしもいえないということに なります。

第二に Ubbelohdeの粗雑な測定について不純物の影響で転移がぼけたとらことは, 不純物の存在によって転栘の，例えば規則度といった様なもの，が大きく変化を受けたと 考えるべきなのでしょうか？ あるいは不純物の存在によって，例えば原子空孔のような， 格子久陥の形式の自由エネルギーが非常に下ってその漂度力非常に上䄯したと考えてもよ いのでしょうか?

関：藤田先生のお話しになったのと全く同意見です。尚, Ubbelohde の物質は defectが出来ているといった程度の不純物の混入ではなく，むっと多量の不純物が入り， 
混晶的になったものと想像されます。そのことは融解曲線の立上りが極めて低温から起っ ていることからあ推察できます。

小泉：最初に黒板にかかれた diagramのうち，あとで説明するといわれた"゙ガラス結

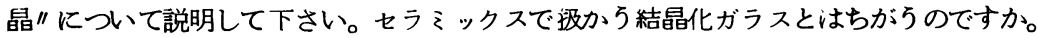

関：これについては本文でややくわしく補足しておきました。シクロへキサノールの例 ですと,このI - 相は柔粘性結晶で, 明らかに Laue 斑点を示す三次元空間格子を形成し ていますが，分子のはげしい熱運動のため，そのスポットの数は限られています。これを 低温に急冷しますと図にみられるように比熱が，あたかもガラス転移と同様になり，その

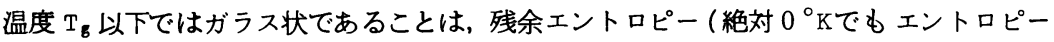
が0にならないこと）をもっていて，この原因は分子の配向等が乱れたままで $0{ }^{\circ} \mathrm{K}$ を凍 結していることを示しています。㫌質問の結晶化ガラスでは Laue spotを示さないので しょらか。よくしりませんが，おそらくもし Laue spotを示すとしても結晶部分とガラ ス部分の heterophaseではないでしょらか。丁度結晶性高分子固体のようになっている のではないでしょうか。したがって一つの純相ではないと考えられます。 